\title{
FY-05 Second Quarter Report On Development Of A Supercritical Carbon Dioxide Brayton Cycle: Improving PBR Efficiency And Testing Material Compatibility
}

NERI Quarterly Progress Report

Chang Oh

Richard Moore

Thomas Lillo

William Windes

Terry Totemeier

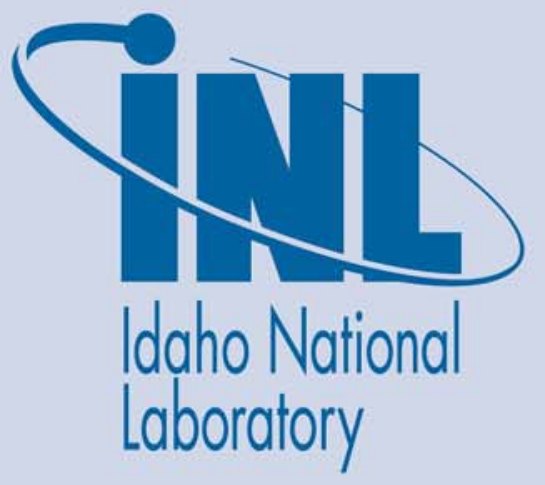
April 2005
The INL is a U.S. Department of Energy National Laboratory operated by Battelle Energy Alliance


INL/EXT-05-00307

\section{FY-05 Second Quarter Report On Development Of A Supercritical Carbon Dioxide Brayton Cycle: Improving PBR Efficiency And Testing Material Compatibility \\ NERI Quarterly Progress Report \\ Chang Oh \\ Richard Moore \\ Thomas Lillo \\ William Windes \\ Terry Toemeier}

April 2005

Idaho National Laboratory

Idaho Falls, Idaho 83415

Prepared for the

U.S. Department of Energy

Assistant Secretary for Nuclear Energy

Under DOE Idaho Operations Office

Contract DE-AC07-05ID14517 


\section{NERI QUARTERLY PROGRESS REPORT}

Project Title: Development of a Supercritical Carbon Dioxide Brayton Cycle: Improving PBR Efficiency and Testing Material Compatibility

Covering Period: January 1, 2004 through March 31, 2004 (2 $2^{\text {nd }}$ quarter report, 2005)

Date of Report: April 30, 2005

Recipient: $\quad$ Kenny Osborne, DOE-ID

Award Number: $\quad$ M2SF 02-0190

Project Number: $\quad 02-190$

Principal

Investigator: Dr. Chang Oh

208-526-7716, Chang.Oh@inl.gov

Collaborators: $\quad$ Richard Moore; 208-526-9671; Richard.Moore@inl.gov

Thomas Lillo; 208-526-9746; Thomas.Lillo@inl.gov

William Windes; 208-526-6985; William.Windes@inel.gov

Terry Totemeier; 208-526-3074; Terry.Totemeier@inl.gov

Project Objective: The objective of this research is to improve a helium Brayton cycle and to develop a supercritical carbon dioxide Brayton cycle for the Pebble Bed Reactor (PBR) that can also be applied to the Fast Gas-Cooled Reactor (FGR) and the Very-High-Temperature GasCooled Reactor (VHTR). The proposed supercritical carbon dioxide Brayton cycle will be used to improve the PBR, FGR, and VHTR net plant efficiency. Another objective of this research is to test materials to be used in the power conversion side at supercritical carbon dioxide conditions. Generally, the optimized Brayton cycle and balance of plant (BOP) to be developed from this study can be applied to Generation-IV reactor concepts. Particularly, we are interested in VHTR because it has a good chance of being built in the near future.

Background: $\quad$ The VHTR configuration is very important along with the choice of the working fluid. We started investigating a number of various VHTR configuration particularly in the power conversion unit. This will be our main focus for the year 3 activities. In conjunction with this main focus, our study will include the combined cycle, cycle with multiple reheat option, the recompression cycle, and others. 
Highlights of the second quarter activities of FY-05 are summarized below:

- The improvement of the cyccle efficiency was investigated using a number of different configurations: Combined cycle, reheat cycle, and other cycles. The configuration includes the hydrogen-generating plant for the cycle efficiency. Preliminary results indicate that the use of $\mathrm{CO}_{2}$ in the combined cycle results in the smaller size of intermediate heat exchanger and turbomachinery, which is the advantage over helium, but the system pressure is higher than that of helium.

- From the aforementioned study, the use of $\mathrm{CO}_{2}$ Brayton cycle for the reheat configuration gives $59 \%$ cycle efficiency. The detailed calculations are being performed.

- The paper entitled "Brayton Cycle for High-temperature Gas-Cooled Reactors", was published in Nuclear Technology, Vol. 149, March 2005. A per entitled "Power Conversion Study for High Temperature Gas-Cooled Reactors", was accepted for presentation at ICAPP-05, which will be held in Seoul, Korea.

- $\quad$ Final, coarse-grained MA $754 \mathrm{CO}_{2}$ corrosion test begun and is projected to run for 500 hours.

- A second long-term supercritical $\mathrm{CO}_{2}$ testing system has been constructed and will enable simultaneous testing of multiple materials at $1000^{\circ} \mathrm{C}$ for exposure times up to 5000 hours.

- The manuscript, entitled "Elevated Temperature Strength of Fine-Grained INCONEL Alloy MA754", was accepted for publication by Metallurgical Transactions, A, and highlights the results of mechanical property testing of finegrained MA 754.

Status:

Task 1. Development of $\mathrm{CO}_{2}$ Brayton Cycle

Tasks 1-1, 1-2, 1-3, 1-4, and 1-5 were completed in the second and the third quarter of FY-03.

Task 2. Improvement of HTGR Net Efficiency

The objective of this task is to improve the overall plant cycle efficiency by the combination of increasing the efficiency of each component in the secondary side of the HTGR. To accomplish this task, we performed a number of HYSYS simulation to investigate a number of different cycle configurations: combined cycle and reheat cycle. In this report, results from the combined cycle are included.

\section{- Combined cycle}

The cycle configuration is shown in Figure 1. 
This indirect configuration is a Brayton cycle and a Rankine cycle.

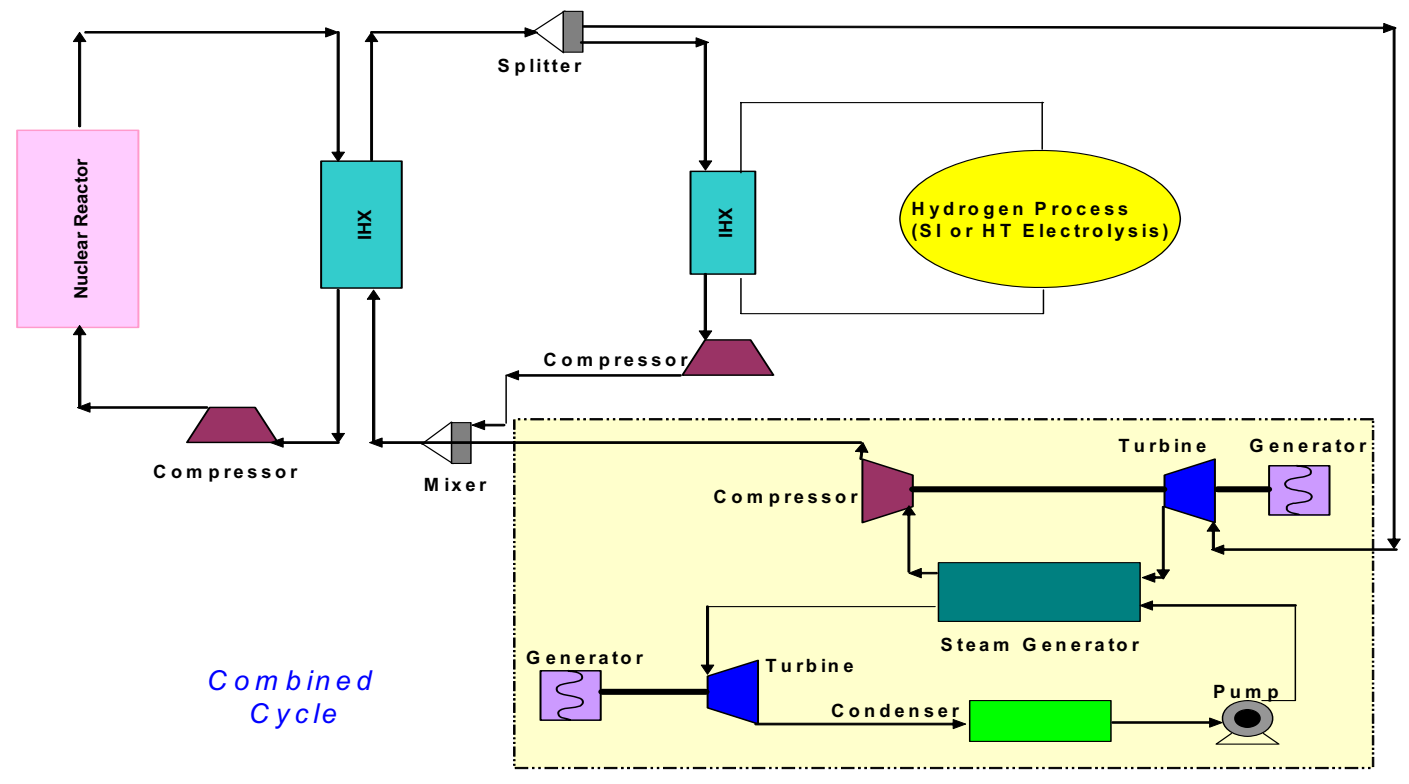

Figure 1. The combined cycle.

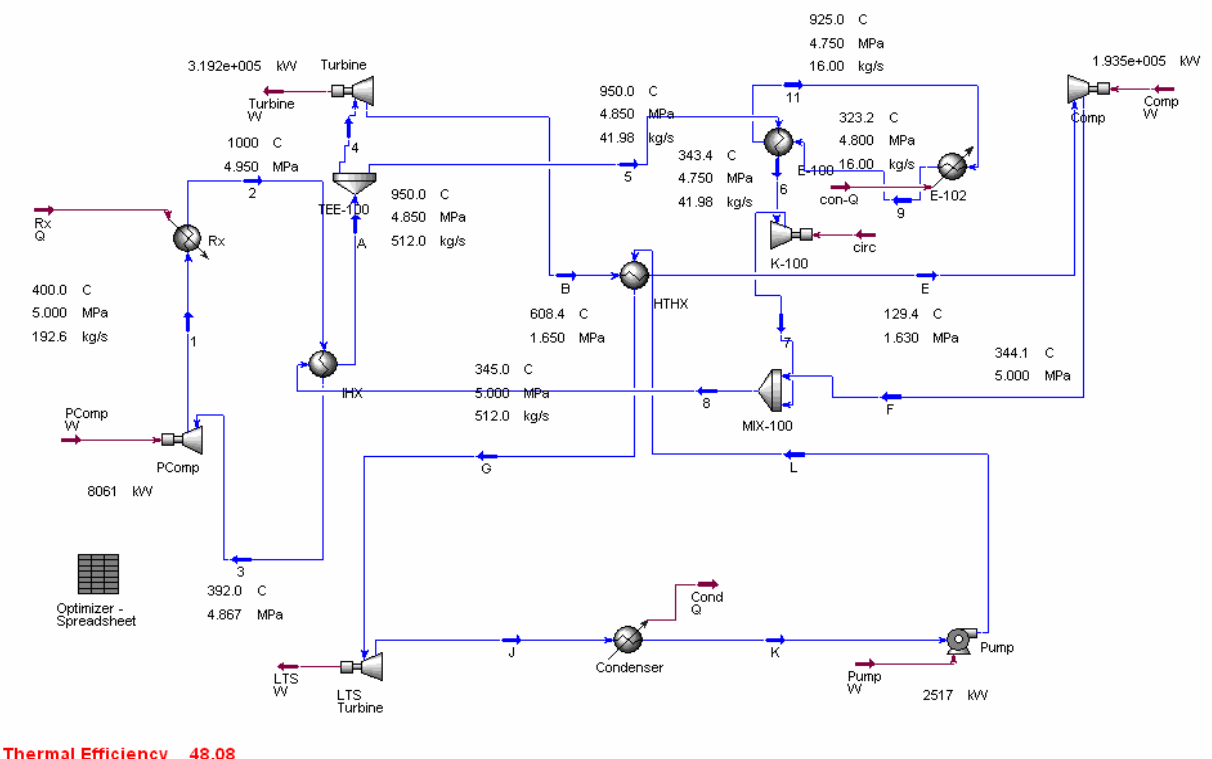

Figure 2. Snapshot of HYSYS model of the combined cycle with $\mathrm{N}_{2} / \mathrm{He}$. 
This configuration was developed by Framatome (Copsy et. al, 2004). Heat from the reactor $(600 \mathrm{MWt})$ is transferred to a power conversion unit in which the heat transfer fluid is a binary mixture of nitrogen ( $80 \%$ by wt.) and helium ( $20 \%$ by weight). The majority of fluid is 0.636 mole fraction of helium vs. 0.364 mole fraction of nitrogen. This indirect cycle design facilitates an improvement of the cycle efficiency using a Rankine bottoming cycle. The key difference of this concept is the reduction of the reactor inlet temperature and lower pressures compared with that of GT-MHR and others. With reduced inlet temperature, the flow rate and circulator power is lower and lower pressures results in less stress problems in material and reduce wall thickness of reactor and other units in the system.

INL developed a combined cycle using $\mathrm{CO}_{2}$ as the working fluid in the Brayton cycle rather than $\mathrm{N}_{2} / \mathrm{He}$ proposed by Framatome. All the operating conditions are considered to be INL's intellectual properties. Table 1 shows the main differences between

Framatome's $\mathrm{N}_{2} / \mathrm{He}$ cycle and $\mathrm{CO} 2$ cycle developed by INL. For these calculations, hydrogen generation process was included in both configurations. In terms of the overall cycle efficiency, the efficiency is nearly the same (48\%) for both configurations. The main advantage of the $\mathrm{CO}_{2}$ cycle over the $\mathrm{N}_{2} / \mathrm{He}$ cycle is that $\mathrm{CO}_{2}$ cycle reduces the size of the intermediate heat exchanger, turbines, and compressors due to the reduced volumetric flow of $\mathrm{CO}_{2}$ compared to $\mathrm{N}_{2}$ /helium.

Table 1. Comparison of the combined $\mathrm{N}_{2} / \mathrm{He}$ and combined with $\mathrm{CO}_{2}$ cycle.

\begin{tabular}{|c|c|c|}
\hline & $\begin{array}{l}\text { Combined } \\
\text { Cycle with } \\
\mathrm{N}_{2} / \text { Helium } \\
\text { in Brayton } \\
\text { Cycle }\end{array}$ & $\begin{array}{l}\text { Combined Cycle with } \\
\mathrm{CO}_{2} \text { in Brayton Cycle }\end{array}$ \\
\hline Reactor Power & $\begin{array}{c}600 \mathrm{MW}- \\
\text { thermal }\end{array}$ & $600 \mathrm{MW}$-thermal \\
\hline Configuration & Indirect & Indirect \\
\hline Fluid in the reactor & Helium & Helium \\
\hline Fluid in Brayton Cycle & $\mathrm{N}_{2} / \mathrm{He}$ & $\mathrm{CO}_{2}$ \\
\hline Reactor Inlet & $\begin{array}{l}400^{\circ} \mathrm{C} \\
5 \mathrm{MPa}\end{array}$ & $\begin{array}{l}400^{\circ} \mathrm{C} \\
5 \mathrm{MPa}\end{array}$ \\
\hline Reactor Outlet & $\frac{1000^{\circ} \mathrm{C}}{4.95 \mathrm{MPa}}$ & $\frac{1000^{\circ} \mathrm{C}}{4.95 \mathrm{MPa}}$ \\
\hline $\mathrm{HX}$ Outlet & $\begin{array}{c}392^{\circ} \mathrm{C} \\
4.867 \mathrm{MPa}\end{array}$ & $\frac{392^{\circ} \mathrm{C}}{4.867 \mathrm{MPa}}$ \\
\hline Turbine Inlet & $\begin{array}{c}1000^{\circ} \mathrm{C} \\
4.95 \mathrm{MPa}\end{array}$ & $\frac{1000^{\circ} \mathrm{C}}{11 \mathrm{MPa}}$ \\
\hline Compressor Inlet & $\begin{array}{c}129.4^{\circ} \mathrm{C} \\
1.63 \mathrm{MPa}\end{array}$ & $\begin{array}{c}119.6^{\circ} \mathrm{C} \\
1.63 \mathrm{MPa}\end{array}$ \\
\hline Hot Pinch temperature & $285.5 \mathrm{C}$ & 305.9 \\
\hline Cold Pinch Temperature & $283.1 \mathrm{C}$ & $282.8 \mathrm{C}$ \\
\hline UA* & $\begin{array}{l}8.61 \mathrm{e} 7 \\
\mathrm{~kJ} / \mathrm{C}-\mathrm{hr}\end{array}$ & $3.03 \mathrm{e} 7 \mathrm{~kJ} / \mathrm{C}-\mathrm{hr}$ \\
\hline Std. Vol. Flow & $4800 \mathrm{~m}^{3} / \mathrm{h}$ & $3489 \mathrm{~m}^{3} / \mathrm{h}$ \\
\hline Cycle Efficiency & $48 \%$ & $48 \%$ \\
\hline
\end{tabular}


UA is the universal heat transfer coefficient and $A$ is the heat transfer area.

\section{- Reheat cycle}

This configuration is shown in Figure 3.

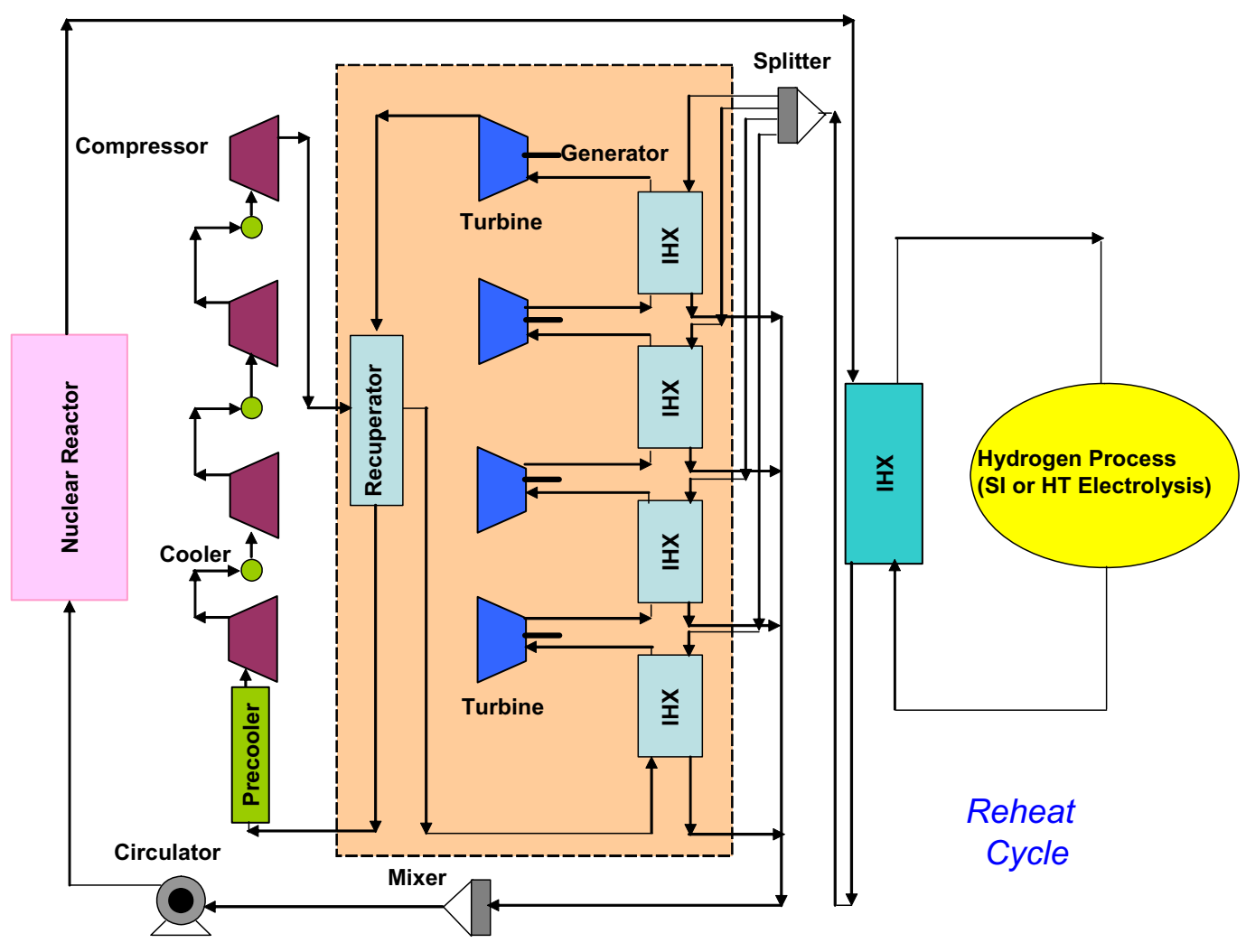

Figure 3. Reheat Cycle with $\mathrm{CO}_{2}$ fluid in the power conversion unit.

The idea of this configuration (Ingersoll et. al, 2004) is to enhance the cycle efficiency by increasing the inlet temperatures to the turbines by using four intermediate heat exchangers. This configuration consists of the primary loop with an intermediate heat exchanger that couples the hydrogen-generating plant. The heat transfer media of the primary loop is helium and $\mathrm{CO}_{2}$ was used in the power conversion unit. The reactor power is $600 \mathrm{MW}$ thermal and the energy to the turbomachinery is transferred to four turbines and compressors. The preliminary calculations indicate that the cycle efficiency is approximately $59 \%$. The detailed calculations are being performed. From the detailed study, the pros and cons of this configuration compared with others will be discussed.

\section{References:}

Copsey, B. et. al., "The Framatome ANP Indirect- Cycle very High Temperature Reactor", Proceedings of ICAPP'04, Pittsburgh, PA, June 13-17, 2004.

Ingersoll, D et. al., "Status of Preconceptual design of the Advanced High-Temperature Reactor", ORNL/TM-2004/104, May, 2004. 


\section{Plans for Next}

We plan to explore further the Brayton cycle improvement using various power conversion configurations. The baseline cases will be established with helium and eventually with high pressure $\mathrm{CO}_{2}$ system for comparison.

There are no concerns and no issues.

Status:

Task 3. Material Compatibility

Testing efforts have been somewhat hampered by the need to move the supercritical $\mathrm{CO}_{2}$ testing system to a new location to accommodate equipment for other programs. During this move the system was dismantled and numerous improvements were made to make the system more reliable and allow for longer exposure times. Modifications to the safety documentation indicating the new location was submitted and approved. Testing will resume 04-25-05.

\section{Task 3-2-2 Corrosion Testing of MA 754 in Supercritical $\mathrm{CO}_{2}$}

Approximately 350 hours of a long-term (500 hour) test has been completed. This is the last coarse-grained sample to be tested at $1000^{\circ} \mathrm{C}$ and 1500 psi. Currently, no indications of sample degradation have been observed (i.e. leaks, system depressurization, or visual observations). After completing the 500 hour test the sample will be sectioned, analyzed, and compared to the previous coarse-grained test samples exposed for shorter periods of time. The corrosion testing is expected to be completed early in the third quarter.

\section{Task 3-2-3}

Fine-grained test samples have been machined and are ready for testing under similar conditions as the coarse samples. Test times will be approximately 100, 250, and 500 hours for these three samples. Analysis results will be compared to the coarse grained samples. Testing will commence as soon as the last large-grained MA 754 corrosion test has been completed (Task 3-2-2).

Task 3-3 Corrosion behavior of I-617 in supercritical $\mathrm{CO}_{2}$

A new $\mathrm{CO}_{2}$ test loop is being constructed to allow long-term testing of I-617 to be performed (up to 5000 hours) at $1000^{\circ} \mathrm{C}$ and 1000 psi. This is an improved test loop system that can test multiple samples simultaneously instead of a single, large hollow tube. Multiple $\sim 6-\mathrm{mm}$ diameter $\times$ 25-mm long samples will be contained within long, thick-walled stainless steel tubes inside a horizontal furnace. A large test sample matrix from the multiple samples can then be generated. In addition, up to 6 different thickwalled tubes can be run simultaneously allowing samples from different materials to be tested within each tube, respectively. Safety considerations require the operating pressure to be reduced to 1000 psi to eliminate the possibility of creep rupture in the stainless tubes. Based upon previous results and experience this lower pressure should not significantly affect the response of the samples during testing. 
The required components have been procured and testing will begin as soon as the system is assembled, approximately 4 weeks.

\section{Plans for Next}

- Complete corrosion testing of coarse-grained MA 754 and compose a manuscript for a peer-reviewed journal reporting the results. Task 3-2-2.

- Begin corrosion testing fine-grained MA 754. Task 3-2-3

- Begin corrosion testing of I-617. Task 3-3-1

\section{Project Milestones}

The project milestones are shown below:

\begin{tabular}{|c|c|c|}
\hline Milestone/Deliverable Description & $\begin{array}{l}\text { Planned } \\
\text { Completion }\end{array}$ & Actual Completion \\
\hline $\begin{array}{l}\text { 1. Development of CO2 Brayton } \\
\text { Cycle }\end{array}$ & 30 June 2003 & Completed \\
\hline $\begin{array}{l}\text { 1-1 Development of the efficiency } \\
\text { equation of turbine and } \\
\text { compressor for the real gas }\end{array}$ & 31 March 2003 & Completed \\
\hline $\begin{array}{l}\text { 1-2 Check of supercritical CO2 } \\
\text { properties with equation of state }\end{array}$ & 31 March 2003 & Completed \\
\hline $\begin{array}{l}\text { 1-3 Selection of the optimization } \\
\text { computer code }\end{array}$ & 31 March 2003 & Completed \\
\hline $\begin{array}{l}\text { 1-4 Layout of CO2 thermal cycle and } \\
\text { initial calculations }\end{array}$ & 31 March 2003 & Completed \\
\hline 1-5 Perform baseline calculations & 30 June 2003 & Completed \\
\hline $\begin{array}{l}\text { 2. Improvement of Brayton cycle } \\
\text { efficiency }\end{array}$ & 30 September 2005 & $\begin{array}{l}\text { Starts in the } 4^{\text {th }} \text { quarter of } \\
\text { FY-03 }\end{array}$ \\
\hline $\begin{array}{l}\text { 2-1. Enhancement of each } \\
\text { component's efficiency }\end{array}$ & 31 March 2004 & $\begin{array}{l}\text { Starts in the } 4^{\text {th }} \text { quarter of } \\
\text { FY-03 }\end{array}$ \\
\hline 2-2. Optimization of PBR schematic & 30 September 2005 & $\begin{array}{l}\text { Starts in the } 2 \text { nd quarter } \\
\text { of FY-04 }\end{array}$ \\
\hline $\begin{array}{l}\text { 2-2-1 Develop PBR optimization } \\
\text { model }\end{array}$ & 30 September 2005 & $\begin{array}{l}\text { Starts in the } 2^{\text {nd }} \text { quarter of } \\
\text { FY-04 }\end{array}$ \\
\hline $\begin{array}{l}\text { 2-2-2 Efficiency and cost comparison } \\
\text { calculations }\end{array}$ & 30 September 2005 & $\begin{array}{l}\text { Starts in the } 2^{\text {nd }} \text { quarter of } \\
\text { FY-04 }\end{array}$ \\
\hline 3. $\quad$ Material testing & 30 September 2005 & In progress \\
\hline $\begin{array}{l}\text { 3-1 Characterization of creep } \\
\text { deformation of MA } 754\end{array}$ & 30 September 2004 & Completed \\
\hline $\begin{array}{l}\text { 3-1-1 Characterization of initial } \\
\text { microstructure }\end{array}$ & 30 June 2003 & Completed \\
\hline
\end{tabular}




\begin{tabular}{|c|c|c|}
\hline $\begin{array}{l}\text { 3-1-2 High temperature mechanical } \\
\text { and creep properties of MA } 754\end{array}$ & 31 December 2003 & Completed \\
\hline $\begin{array}{l}\text { 3-1-3 Mechanical and creep } \\
\text { properties fine-grained MA } 754\end{array}$ & 31 August 2004 & Completed \\
\hline 3-2 Thermogravimetric analyses & 30 April 2005 & In progress \\
\hline $\begin{array}{l}\text { 3-2-1 Design and construction of } \\
\text { supercritical CO2 test loop }\end{array}$ & 30 June 2003 & Completed \\
\hline $\begin{array}{l}\text { 3-2-2 Corrosion testing of MA } 754 \text { in } \\
\text { supercritical CO2 }\end{array}$ & 30 April 2005 & In progress \\
\hline $\begin{array}{l}\text { 3-3 Corrosion behavior of I-617 in } \\
\text { supercritical } \mathrm{CO}_{2}\end{array}$ & 31 August 2005 & Starts $2^{\text {nd }}$ quarter of FY05 \\
\hline 3-3-1 - Corrosion rate determination & 31 August 2005 & \\
\hline $\begin{array}{l}\text { 3-3-2 - Composition of Corrosion } \\
\text { products }\end{array}$ & 31 August 2005 & \\
\hline $\begin{array}{l}\text { 3-4 Final report on corrosion behavior } \\
\text { of MA } 754 \text { and I-617 in } \\
\text { supercritical } \mathrm{CO}_{2}\end{array}$ & 30 September 2005 & Starts $4^{\text {th }}$ quarter of FY05 \\
\hline
\end{tabular}

\begin{tabular}{|c|c|c|c|c|c|c|c|c|c|c|c|c|}
\hline \multirow{2}{*}{ Project Mlestone/Deliverable Summary } & \multicolumn{4}{|c|}{ FY03 } & \multicolumn{4}{|c|}{ FY04 } & \multicolumn{4}{|c|}{ FY05 } \\
\hline & Q1 & Q2 & Q3 & Q4 & Q1 & Q2 & Q3 & Q4 & Q1 & Q2 & Q3 & Q4 \\
\hline \\
\hline $\begin{array}{l}\text { 1-1 Development of the efficiency equation of turbine and } \\
\text { compressor for the real gas }\end{array}$ & & & & & & & & & & & & \\
\hline \multirow{2}{*}{\multicolumn{13}{|c|}{$\begin{array}{l}\text { 1-2 Che ch of supercitical } \mathrm{CO}_{2} \text { properties with equation of state } \\
\text { 1.3 Selection of the optimization computer code }\end{array}$}} \\
\hline & & & & & & & & & & & & \\
\hline \multicolumn{13}{|l|}{ 1.4 Layout of the $\mathrm{CO}_{2}$ themal orcle and initial calculations } \\
\hline \multicolumn{13}{|l|}{ 1.5 Perfom baseline calculations } \\
\hline \multicolumn{13}{|l|}{ 2. Improvement of Brayton Cycle Efficiency } \\
\hline \multicolumn{13}{|l|}{ 2-1 Enhancement of each component's efficiency } \\
\hline \multicolumn{13}{|l|}{ 2-2 Optimization of PBR schematic } \\
\hline \multicolumn{13}{|l|}{ 2-2-1 Develop PBR optimization model } \\
\hline \multicolumn{13}{|l|}{ 2-2-2 Efficienos and cost companison calculations } \\
\hline \multicolumn{13}{|l|}{ 3. Material testing } \\
\hline \\
\hline \multicolumn{13}{|l|}{ 3-1-1 Characterization of initial microstructure } \\
\hline \multicolumn{13}{|l|}{$\begin{array}{l}\text { 3-1-2 High temperature mechanical and creep properties } \\
\text { of MA754 }\end{array}$} \\
\hline \multicolumn{13}{|l|}{$\begin{array}{l}\text { 3-1-3 Mechanical and creep properties of thermo- } \\
\text { mechanically processed MA 754 }\end{array}$} \\
\hline \multicolumn{13}{|l|}{ 3-2 Thermogravimetric analyses } \\
\hline \multirow{2}{*}{\multicolumn{13}{|c|}{$\begin{array}{l}\text { 3-2-1 Design and construction of supercritical } \mathrm{CO}_{2} \text { test loop } \\
\text { 3-2-2 Corrosion testing of MA754 in supercritical } \mathrm{CO}_{2}\end{array}$}} \\
\hline & & & & & & & & & & & & \\
\hline \multicolumn{13}{|l|}{ 3-3 Corrosion behavior of $\mathrm{I}-617$ in supercritical $\mathrm{CO} 2$} \\
\hline \multicolumn{13}{|l|}{ 3-3-1 Corrosion rate determination } \\
\hline \multicolumn{13}{|l|}{ 3-3-2 Composition of corrosion products } \\
\hline \multicolumn{13}{|l|}{$\begin{array}{l}\text { 3.4 Final report on corrosion behavior of MA } 754 \text { and I-617 } \\
\text { in supercritical } C O 2\end{array}$} \\
\hline - Completion & & & & & & & & & & & & \\
\hline
\end{tabular}

